\title{
Renal Pelvis and Ureter Cancer Pathologic Distant Metastasis TNM Finding v8
}

National Cancer Institute

\section{Source}

National Cancer Institute. Renal Pelvis and Ureter Cancer Pathologic Distant Metastasis

TNM Finding v8. NCI Thesaurus. Code C140337.

A pathologic finding about one or more characteristics of renal pelvis and ureter cancer, following the rules of the TNM AJCC v8 classification system as they pertain to distant metastases. 